\title{
A bibliometric analysis of classic publications in web of science category of orthopedics
}

\author{
Yunzhu Li ${ }^{1 \dagger}$, Gang Xü ${ }^{2 \dagger}$, Xiao Long ${ }^{1,4^{*}}$ (D) and Yuh-Shan $\mathrm{Ho}^{3^{*}}$
}

\begin{abstract}
Background: The past century has witnessed the rapid development of operation technique, surgical instruments, and knowledge of the diseases in orthopedics. In the academic history, a number of classic papers boosted the advancement for surgery. In this paper, we performed a bibliometric analysis, aiming to determine the most influential studies within the field.
\end{abstract}

Methods: Articles were searched from the publication year of 1900 to 2016 according to the Science Citation Index Expanded database of the Clarivate Analytics Web of Science Core Collection database. Two citation indicators $T C_{\text {year }}$ and $C_{\text {year }}$ were employed to characterize the classic articles and the articles were identified and analyzed.

Results: A total of 30 classic articles with $T C_{2016} \geq 1000$ in Web of Science category of orthopedics were identified, all written in English between 1961 and 2007 by nine countries. The minimal value of $T C_{2016}$ was 1010; the maximum 3570; and the average 1591. Thirty classic articles were published in eight journals that were listed in the Web of Science category of orthopedics in 2016, and in two other orthopedics journals that were no longer tracked by Web of Science category of orthopedics as of 2016. Among the top 10 cited articles in both $T C_{2016}$ and $C_{2016}$, five articles barely received attention in the first few years after their publication, while they became cited more and more frequently in the last decade.

Conclusion: This study evaluated the development and trend of orthopedics research by adopting bibliometric analysis. It serves as a guide for investigators in the future research.

Keywords: Orthopedics, Bibliometric, Classic publications, Web of science

\section{Background}

The modern term orthopedics derives from the older word orthopaedia, title of a book published in 1741 by Nicholas Andry [1]. Two Greek words orthos and paedios serve as roots for orthopedic surgery. The former one means straight and free of deformity and the latter one means a child [2]. Orthopedic surgery demonstrates a rapid progress with several recent advances noted within orthopedic subspecialties [3-5],

\footnotetext{
*Correspondence: pumclongxiao@126.com; ysho@asia.edu.tw

${ }^{\dagger}$ Yunzhu Li and Gang Xu contributed equally to this work.

${ }^{1}$ Department of Plastic Surgery, Peking Union Medical College (PUMC) Hospital, PUMC and Chinese Academy of Medical Sciences, Beijing, China

${ }^{3}$ Trend Research Centre, Asia University, No. 500, Lioufeng Road, Wufeng, Taichung Country 41354, Taiwan

Full list of author information is available at the end of the article
}

basic science [6], and clinical research [7]. Bibliometrics is a widely used tool to map the literature around a research field. It can help us to gain insight into the research focuses and future development of trends in orthopedic surgery. The citation number of a published article approximately reflects the popularity of the study and indicates the significance of the article in a certain field [8]. A thorough bibliometric analysis of classic articles helps investigators efficiently learns the history of developments and future directions of a research field. In this study, classic articles were identified and their characteristics were analyzed based on the bibliometric analysis method in the hope that it may guide investigators in this field.

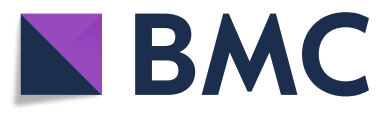

(c) The Author(s). 2019 Open Access This article is distributed under the terms of the Creative Commons Attribution 4.0 International License (http://creativecommons.org/licenses/by/4.0/), which permits unrestricted use, distribution, and reproduction in any medium, provided you give appropriate credit to the original author(s) and the source, provide a link to the Creative Commons license, and indicate if changes were made. The Creative Commons Public Domain Dedication waiver (http://creativecommons.org/publicdomain/zero/1.0/) applies to the data made available in this article, unless otherwise stated. 


\section{Materials and methods}

Our study was based on the Science Citation Index Expanded (SCI-EXPANDED) database of the Clarivate Analytics (formerly known as the Thomson Reuters and the Institute for Scientific Information) Web of Science (WOS) Core Collection database. According to Journal Citation Reports (JCR) of 2016 (InCites Journal Citation Reports dataset updated September 09, 2017), it indexes 8879 journals with citation references across 177 WOS categories in SCI-EXPANDED. In total, 302,299 documents (including 227,023 articles) were found in WOS category of orthopedics from the publication of 1900 to 2016 based on SCI-EXPANDED (updated on March 12, 2018). Two citation indicators $T C_{\text {year }}$ and $C_{\text {year }}$ were employed to characterize the classic articles. $T C_{\text {year }}$ is the total citation number from WOS Core Collection since publication to the end of the most recent year $[9,10]$. $C_{\text {year }}$ is the number of citations in the most recent year. $C_{2016}$ means the number of citation in 2016. $T C_{\text {year }} \geq 1000$ was used to retrieve the classic articles [11-13]. We inserted all the data for each article for each year into spreadsheet software, and manipulated them using Microsoft Excel2016 [14, 15]. In addition, all hard copies of the 32 classic publications were found to check analysis information. Affiliations in England, Scotland, Northern Ireland, and Wales were reclassified as being from the United Kingdom (UK) [16].

\section{Results and discussion}

\section{Document type and language of publication}

Analysis of document types and their citations per publication was earlier proposed [17]. A total of 32 classic publications $\left(0.011 \%\right.$ of 302,299 documents) with $T C_{2016} \geq$ 1000 in WOS of orthopedics were found within two document types indexed in the WOS. Thirty classic publications were found to be document type of article including three of them belonging to both document types of article and proceedings paper. Two were published as document type of review. A review entitled "OARSI recommendations for the management of hip and knee osteoarthritis, Part II: OARSI evidence-based, expert consensus guidelines" [18] was the only classic document published in the latest year of 2008 in orthopedics field with $T C_{2016}$ of 1394. Only articles were used for subsequent analysis because they included complete research ideas and results [19]. As a result, we identified 30 classic articles $(0.013 \%$ of 227,023 articles) in the category of orthopedics, all of which were written in English. Such low percentage of classic publications can be also found, for example $0.048 \%$ and $0.063 \%$ of all documents in WOS categories of neurosciences [20] and psychology [12] respectively as well as $0.046 \%$ and $0.0049 \%$ of all articles in WOS categories of neurosciences [20] and surgery [11] respectively.

\section{Publication years}

In recent years, Ho's group proposed a relationship between total number of classic articles in a year $(T P)$ and their citations per publication $\left(C P P_{2016}=T C_{2016}\right)$ $T P$ ) by the decades in a WOS category as a unique indicator, for example WOS category of surgery [11], psychology [12], and neurosciences [20]. Thirty classic articles in WOS category of orthopedics were published between 1961 and 2007. The maximum value of $T C_{2016}$ was 3570 , the minimum 1010, and the average 1591. Figure 1 shows the distribution of these 30 classic articles over the decades, and their citations per publication $\left(C P P_{2016}\right)$. The 30 classic articles received a total of 47,735 citations. Only two classic articles were found in the decade of the 1960s, and no classic article was identified in the most recent decades. The 1980s was the most prolific period in terms of classic articles in orthopedics, which was different from WOS categories of the 1970s in surgery [11], the 1970s in psychology [12], and the 1990s in neurosciences [20]. Besides, the decade of the 1960s had the highest $C P P_{2016}$ of 2401 . The earliest classic article in orthopedics field was "The etiology of chondromalacia patellae" [21] published in the Journal of Bone and Joint Surgery-British Volume by Outerbridge from Royal Columbian Hospital in Canada in 1961 with $T C_{2016}$ of 1331 (ranked 19th) and $C_{2016}$ of 78 (ranked 22th). The latest classic article was found in 2007 by five authors from Exponent Inc., entitled "Projections of primary and revision hip and knee arthroplasty in the United States from 2005 to 2030" [22] in the Journal of Bone and Joint Surgery-American Volume with $T C_{2016}$ of 2012 (ranked 6th) and $C_{2016}$ of 411 (ranked 1 st).

\section{Journals}

A total of 76 journals were listed in the WOS category of orthopedics in 2016. The 30 classic articles were published in eight of these journals $(11 \%$ of 76 journals), and in two other orthopedics journals that were no longer tracked by Web of Science category of orthopedics as of 2016 (Table 1). The Journal of Bone and Joint Surgery-American Volume with $I F_{2016}$ of 4.840 (rank 2nd of 76 orthopedics journals) published the largest number of classic articles with nine articles (30\% of 30 classic articles), followed by Clinical Orthopedics and Related Research with seven. American Journal of Sports Medicine had the highest $I F_{2016}$ with only one classic article. Connective Tissue Research with $I F_{2016}$ of 1.832 (ranked 33th) also had only one classic article. The Journal of Bone and Joint Surgery-British Volume $\left(I F_{2014}=3.309\right)$ and Acta Orthopaedica Scandinavica $\left(I F_{2004}=1.108\right)$ were not in SCI-EXPANDED in 2014 and 2004 respectively. 


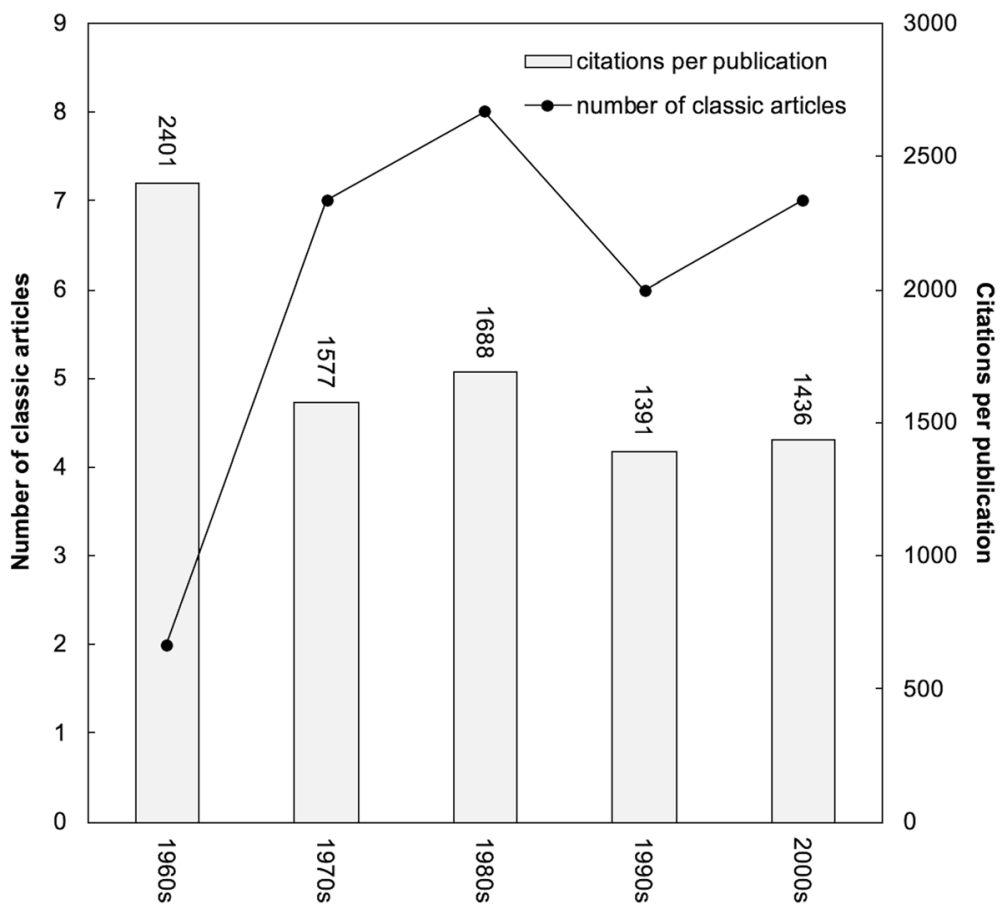

Fig. 1 Number of classic articles and citations per publication by decade

\section{Countries, institutions, and authors}

There were 30 classic articles in WOS category of orthopedics by nine countries. Twenty-seven articles (90\% of 30 articles) were completed in a single country from five countries and three (10\%) were completed international-collaboratively from six countries. The USA took the first place by total classic articles with 18 (60\% of 30 articles), followed by the UK (six articles; $20 \%$ of 30 articles), Sweden (three; 10\%),

Table 1 The ten journals with classic articles in Web of Science category of orthopedics

\begin{tabular}{lll}
\hline Journal & $T P(\%)$ & $I_{2016}\left(\mathrm{rank}^{*}\right)$ \\
\hline $\begin{array}{l}\text { Journal of Bone and Joint Surgery-American } \\
\text { Volume }\end{array}$ & $9(30)$ & $4.840(2)$ \\
Clinical Orthopedics and Related Research & $7(23)$ & $3.897(6)$ \\
Spine & $4(13)$ & $2.499(20)$ \\
Physical Therapy & $3(10)$ & $2.764(14)$ \\
Journal of Orthopedic Research & $2(6.7)$ & $2.692(16)$ \\
Acta Orthopaedica Scandinavica & $1(3.3)$ & $1.108 \mathrm{in} \mathrm{2004}$ \\
American Journal of Sports Medicine & $1(3.3)$ & $5.673(1)$ \\
Connective Tissue Research & $1(3.3)$ & $1.832(33)$ \\
Foot \& Ankle International & $1(3.3)$ & $1.872(32)$ \\
Journal of Bone and Joint Surgery-British & $1(3.3)$ & $3.309 \mathrm{in} \mathrm{2014}$ \\
Volume & &
\end{tabular}

$T P$ total number of classic articles, $I F_{2016}$ impact factor for 2016 ; ${ }^{*}$ : rank of $I F_{2016}$ in Web of Science category of orthopedics
Canada (two; 6.7\%), and one for each of Australia, Brazil, France, Japan, and Switzerland respectively. The USA also published 16 of 27 single-country articles, two of three internationally collaborative articles, 16 of 30 first author articles, 14 of 28 corresponding articles, and four of five single-author articles.

In total, $18(60 \%$ of 30 articles $)$ articles were completed in a single institution from 17 institutions and $12(40 \%)$ were completed inter-institutionalcollaboratively from 31 institutions. Only two institutions such as Case Western Reserve University in USA and Linköping University Hospital in Sweden published two classic articles in WOS category of orthopedics. Other 45 institutions had only one classic article. Linköping University Hospital was also the only one that published two single institution classic articles, first author articles, and corresponding author articles. Twenty-two of the 47 classic institutions were located in the USA followed by nine from the UK, five from Canada, three from Sweden, three from Australia, two from Japan, and one from Switzerland, France, and Brazil respectively.

Among the 91 classic authors of the 20 classic articles in WOS category of orthopedics, only A.I. Caplan from Case Western Reserve University in the USA and J. Lysholm from Linköping University Hospital in Sweden published two classic articles including one first author and one corresponding author articles. A.I. Caplan also 
Table 2 Authors with classic articles in Web of Science category of orthopedics

\begin{tabular}{|c|c|c|c|c|c|}
\hline Author & Institution & Rank (TP) & Rank (FP) & Rank (RP) & Rank (SP) \\
\hline A.I. Caplan & Case Western Reserve University, USA & $1(2)$ & $1(1)$ & $1(1)$ & $1(1)$ \\
\hline J. Lysholm & Linkoping University Hospital, Sweden & $1(2)$ & $1(1)$ & $1(1)$ & N/A \\
\hline R.S. Adelaar & N/A & $3(1)$ & $\mathrm{N} / \mathrm{A}$ & N/A & N/A \\
\hline T. Albrektsson & University of Gothenburg, Sweden & $3(1)$ & $1(1)$ & $1(1)$ & N/A \\
\hline I.J. Alexander & N/A & $3(1)$ & N/A & N/A & N/A \\
\hline H.C. Amstutz & N/A & $3(1)$ & N/A & N/A & N/A \\
\hline J.T. Anderson & N/A & $3(1)$ & N/A & N/A & N/A \\
\hline A.J. Barrett & N/A & $3(1)$ & N/A & N/A & N/A \\
\hline D.E. Beaton & Institute for Work and Health, Canada & $3(1)$ & $1(1)$ & $1(1)$ & N/A \\
\hline M. Beck & N/A & $3(1)$ & N/A & N/A & N/A \\
\hline S.D. Boden & George Washington University, USA & $3(1)$ & $1(1)$ & $1(1)$ & N/A \\
\hline R.W. Bohannon & Cape Fear Valley Medical Center, USA & $3(1)$ & $1(1)$ & $1(1)$ & N/A \\
\hline C. Bombardier & N/A & $3(1)$ & N/A & $\mathrm{N} / \mathrm{A}$ & N/A \\
\hline J.W. Bowerman & N/A & $3(1)$ & N/A & N/A & N/A \\
\hline P.I. Branemark & N/A & $3(1)$ & N/A & N/A & N/A \\
\hline A.F. Brooker & Johns Hopkins Hospital, USA & $3(1)$ & $1(1)$ & N/A & N/A \\
\hline D.R. Carter & University of Washington, USA & $3(1)$ & $1(1)$ & N/A & N/A \\
\hline J. Charnley & Charnley, UK & $3(1)$ & N/A & $1(1)$ & N/A \\
\hline C.R. Constant & Addenbrooke's Hospital, UK & $3(1)$ & $1(1)$ & $1(1)$ & N/A \\
\hline D.O. Davis & N/A & $3(1)$ & N/A & N/A & N/A \\
\hline J.G. Delee & Wrightington Hospital, UK & $3(1)$ & $1(1)$ & N/A & N/A \\
\hline T.S. Dina & N/A & $3(1)$ & N/A & N/A & N/A \\
\hline H. Dorfman & $\mathrm{N} / \mathrm{A}$ & $3(1)$ & N/A & N/A & N/A \\
\hline L.D. Dorr & $\mathrm{N} / \mathrm{A}$ & $3(1)$ & N/A & N/A & N/A \\
\hline W. Dunham & $\mathrm{N} / \mathrm{A}$ & $3(1)$ & $\mathrm{N} / \mathrm{A}$ & N/A & N/A \\
\hline M. Elkins & N/A & $3(1)$ & N/A & N/A & N/A \\
\hline W.F. Enneking & University of Florida, USA & $3(1)$ & $1(1)$ & $1(1)$ & N/A \\
\hline J.C.T. Fairbank & Nuffield Orthopedic Centre, UK & $3(1)$ & $1(1)$ & $1(1)$ & N/A \\
\hline R.W. Farndale & Strangeways Research Laboratory, UK & $3(1)$ & $1(1)$ & $1(1)$ & N/A \\
\hline M.B. Ferraz & N/A & $3(1)$ & N/A & N/A & N/A \\
\hline R. Ganz & University of Berne, Switzerland & $3(1)$ & $1(1)$ & $1(1)$ & N/A \\
\hline M.C. Gebhardt & $\mathrm{N} / \mathrm{A}$ & $3(1)$ & $\mathrm{N} / \mathrm{A}$ & N/A & N/A \\
\hline J. Gillquist & $\mathrm{N} / \mathrm{A}$ & $3(1)$ & N/A & N/A & N/A \\
\hline V.M. Goldberg & N/A & $3(1)$ & N/A & N/A & N/A \\
\hline T. Goto & $\mathrm{N} / \mathrm{A}$ & $3(1)$ & N/A & N/A & N/A \\
\hline T.A. Gruen & Univ Calif Los Angeles, USA & $3(1)$ & $1(1)$ & N/A & N/A \\
\hline F. Guillemin & $\mathrm{N} / \mathrm{A}$ & $3(1)$ & $\mathrm{N} / \mathrm{A}$ & N/A & N/A \\
\hline R.B. Gustilo & Hennepin County Medical Center, USA & $3(1)$ & $1(1)$ & N/A & N/A \\
\hline M. Halpern & $\mathrm{N} / \mathrm{A}$ & $3(1)$ & N/A & N/A & N/A \\
\hline H.A. Hansson & $\mathrm{N} / \mathrm{A}$ & $3(1)$ & N/A & N/A & N/A \\
\hline W.H. Harris & Massachusetts General Hospital, USA & $3(1)$ & $1(1)$ & $1(1)$ & $1(1)$ \\
\hline W.C. Hayes & N/A & $3(1)$ & N/A & N/A & N/A \\
\hline R.D. Herbert & N/A & $3(1)$ & N/A & N/A & N/A \\
\hline J.N. Insall & Hospital for Special Surgery, USA & $3(1)$ & $1(1)$ & $1(1)$ & N/A \\
\hline
\end{tabular}


Table 2 Authors with classic articles in Web of Science category of orthopedics (Continued)

\begin{tabular}{|c|c|c|c|c|c|}
\hline Author & Institution & Rank (TP) & Rank (FP) & Rank (RP) & Rank (SP) \\
\hline M.P. Kadaba & Helen Hayes Hospital, USA & $3(1)$ & $1(1)$ & $1(1)$ & $\mathrm{N} / \mathrm{A}$ \\
\hline H.B. Kitaoka & Mayo Clinic \& Mayo Foundation, USA & $3(1)$ & $1(1)$ & $1(1)$ & N/A \\
\hline S. Kurtz & Exponent Inc., USA & $3(1)$ & $1(1)$ & $1(1)$ & N/A \\
\hline E. Lau & N/A & $3(1)$ & N/A & N/A & N/A \\
\hline M. Leunig & N/A & $3(1)$ & N/A & N/A & N/A \\
\hline J. Lindstrom & N/A & $3(1)$ & N/A & N/A & N/A \\
\hline L. Lippiell & N/A & $3(1)$ & N/A & $\mathrm{N} / \mathrm{A}$ & N/A \\
\hline C.G. Maher & University of Sydney, Australia & $3(1)$ & $1(1)$ & $1(1)$ & N/A \\
\hline M. Malawar & N/A & $3(1)$ & N/A & N/A & N/A \\
\hline H.J. Mankin & Hospital for Joint Diseases, USA & $3(1)$ & $1(1)$ & N/A & N/A \\
\hline J.M. Mansour & N/A & $3(1)$ & N/A & $\mathrm{N} / \mathrm{A}$ & N/A \\
\hline G.M. Mcneice & N/A & $3(1)$ & N/A & N/A & N/A \\
\hline R. Morris & N/A & $3(1)$ & N/A & $\mathrm{N} / \mathrm{A}$ & N/A \\
\hline A.M. Moseley & N/A & $3(1)$ & N/A & N/A & N/A \\
\hline F. Mowat & N/A & $3(1)$ & N/A & N/A & N/A \\
\hline A.H.G. Murley & N/A & $3(1)$ & N/A & N/A & N/A \\
\hline M.S. Myerson & N/A & $3(1)$ & N/A & $\mathrm{N} / \mathrm{A}$ & N/A \\
\hline C.S. Neer & Columbia University, USA & $3(1)$ & $1(1)$ & $1(1)$ & $1(1)$ \\
\hline H. Notzli & N/A & $3(1)$ & N/A & N/A & N/A \\
\hline J.A. Nunley & N/A & $3(1)$ & N/A & N/A & N/A \\
\hline K. Ong & N/A & $3(1)$ & N/A & N/A & $\mathrm{N} / \mathrm{A}$ \\
\hline R.E. Outerbridge & Royal Columbian Hospital, Canada & $3(1)$ & $1(1)$ & $1(1)$ & $1(1)$ \\
\hline J. Parvizi & N/A & $3(1)$ & N/A & N/A & N/A \\
\hline N.J. Patronas & N/A & $3(1)$ & N/A & N/A & N/A \\
\hline S.J. Pineda & N/A & $3(1)$ & N/A & N/A & N/A \\
\hline D.J. Pritchard & N/A & $3(1)$ & N/A & N/A & N/A \\
\hline P.B. Pynsent & N/A & $3(1)$ & N/A & N/A & N/A \\
\hline H.K. Ramakrishnan & N/A & $3(1)$ & N/A & N/A & N/A \\
\hline L.H. Riley & N/A & $3(1)$ & N/A & N/A & N/A \\
\hline R.A. Robinson & N/A & $3(1)$ & N/A & N/A & N/A \\
\hline M. Roland & St. Thomas' Hospital Medical School, UK & $3(1)$ & $1(1)$ & $1(1)$ & N/A \\
\hline M. Sanders & N/A & $3(1)$ & N/A & N/A & N/A \\
\hline C.A. Sayers & N/A & $3(1)$ & N/A & N/A & N/A \\
\hline R.D. Scott & N/A & $3(1)$ & N/A & N/A & N/A \\
\hline W.N. Scott & N/A & $3(1)$ & N/A & N/A & N/A \\
\hline C. Sherrington & N/A & $3(1)$ & N/A & N/A & N/A \\
\hline K.A. Siebenrock & N/A & $3(1)$ & N/A & N/A & N/A \\
\hline J. Sim & Keele University, UK & $3(1)$ & $1(1)$ & $1(1)$ & N/A \\
\hline M.B. Smith & $\mathrm{N} / \mathrm{A}$ & $3(1)$ & N/A & N/A & N/A \\
\hline Y. Tegner & Linkoping University Hospital, Sweden & $3(1)$ & $1(1)$ & $1(1)$ & N/A \\
\hline S. Wakitani & Osaka University Hospital, Japan & $3(1)$ & $1(1)$ & $1(1)$ & N/A \\
\hline J.E. Ware & Quality Metric Inc., USA & $3(1)$ & $1(1)$ & $1(1)$ & $1(1)$ \\
\hline S.W. Wiesel & N/A & $3(1)$ & N/A & N/A & N/A \\
\hline M.E. Wootten & N/A & $3(1)$ & N/A & N/A & N/A \\
\hline
\end{tabular}


Table 2 Authors with classic articles in Web of Science category of orthopedics (Continued)

\begin{tabular}{llllll}
\hline Author & Institution & Rank (TP) & Rank (FP) & Rank (RP) & Rank (SP) \\
\hline C.C. Wright & N/A & $3(1)$ & N/A & N/A N/A \\
R.G. Young & N/A & $3(1)$ & N/A & N/A & N/A
\end{tabular}

$T P$ total number of classic articles, $F P$ number of first author classic articles, $R P$ number of corresponding author classic articles, $S P$ number of single author classic articles

Table 3 The 30 classic articles in Web of Science category of orthopedics

\begin{tabular}{|c|c|c|c|}
\hline $\operatorname{Rank}\left(T C_{2016}\right)$ & $\operatorname{Rank}\left(C_{2016}\right)$ & Article author & Article title \\
\hline $1(3470)$ & $3(253)$ & Harris (1969) [23] & $\begin{array}{l}\text { Traumatic arthritis of hip after dislocation and acetabular fractures: treatment } \\
\text { by mold arthroplasty: an end-result study using a new method of result } \\
\text { evaluation }\end{array}$ \\
\hline $2(2169)$ & $5(197)$ & Bohannon and Smith (1987) [24] & Interrater reliability of a modified Ashworth scale of muscle spasticity \\
\hline $3(2161)$ & $9(161)$ & Insall et al. (1989) [25] & Rationale of the knee society clinical rating system \\
\hline $4(2115)$ & $13(150)$ & Caplan (1991) [26] & Mesenchymal stem cells \\
\hline $5(2058)$ & $16(107)$ & Constant and Murley (1987) [27] & A clinical method of functional assessment of the shoulder \\
\hline $6(2012)$ & $1(411)$ & Kurtz et al. (2007) [22] & $\begin{array}{l}\text { Projections of primary and revision hip and knee arthroplasty in the United States } \\
\text { from } 2005 \text { to } 2030\end{array}$ \\
\hline $7(1870)$ & $2(363)$ & Beaton et al. (2000) [28] & Guidelines for the process of cross-cultural adaptation of self-report measures \\
\hline $8(1817)$ & $26(53)$ & Brooker et al. (1973) [29] & $\begin{array}{l}\text { Ectopic ossification following total hip replacement: Incidence and a method of } \\
\text { classification }\end{array}$ \\
\hline 9 (1816) & $18(97)$ & Gustilo and Anderson (1976) [30] & $\begin{array}{l}\text { Prevention of infection in the treatment of one thousand and twenty-five open } \\
\text { fractures of long bones: Retrospective and prospective analyses }\end{array}$ \\
\hline $10(1811)$ & $17(99)$ & Roland and Morris (1983) [31] & $\begin{array}{l}\text { A study of the natural history of back pain. Part I. Development of a reliable and } \\
\text { sensitive measure of disability in low-back pain }\end{array}$ \\
\hline $11(1771)$ & $15(110)$ & Gruen et al. (1979) [32] & $\begin{array}{l}\text { "Modes of failure" of cemented stem-type femoral components: A radiographic } \\
\text { analysis of loosening }\end{array}$ \\
\hline $12(1764)$ & $8(163)$ & Kitaoka et al. (1994) [33] & Clinical rating systems for the ankle-hindfoot, midfoot, hallux, and lesser toes \\
\hline $13(1674)$ & $10(159)$ & Tegner and Lysholm (1985) [34] & Rating systems in the evaluation of knee ligament injuries \\
\hline $14(1666)$ & $24(67)$ & Mankin et al. (1971) [35] & $\begin{array}{l}\text { Biochemical and metabolic abnormalities in articular cartilage from osteo-arthritic } \\
\text { human hips. II. Correlation of morphology with biochemical and metabolic data }\end{array}$ \\
\hline $15(1440)$ & $19(85)$ & Delee and Charnley (1976) [36] & Radiological demarcation of cemented sockets in total hip replacement \\
\hline $16(1394)$ & $4(229)$ & Fairbank and Pynsent (2000) [37] & The Oswestry Disability Index \\
\hline $17(1367)$ & $21(80)$ & Albrektsson et al. (1981) [38] & $\begin{array}{l}\text { Osseointegrated titanium implants: Requirements for ensuring a long-lasting, } \\
\text { direct bone-to-implant anchorage in man }\end{array}$ \\
\hline $18(1365)$ & $7(177)$ & Ware (2000) [39] & SF-36 health survey update \\
\hline $19(1331)$ & $22(78)$ & Outerbridge (1961) [21] & The etiology of chondromalacia patellae \\
\hline $20(1306)$ & $27(46)$ & Neer (1972) [40] & $\begin{array}{l}\text { Anterior acromioplasty for chronic impingement syndrome in shoulder: A } \\
\text { preliminary report }\end{array}$ \\
\hline $21(1226)$ & $12(151)$ & Ganz et al. (2003) [41] & Femoroacetabular impingement: A cause for osteoarthritis of the hip \\
\hline $22(1225)$ & $23(74)$ & Lysholm and Gillquist (1982) [42] & $\begin{array}{l}\text { Evaluation of knee ligament surgery results with special emphasis on use of } \\
\text { a scoring scale }\end{array}$ \\
\hline $23(1220)$ & $28(39)$ & Carter and Hayes (1977) [43] & The compressive behavior of bone as a two-phase porous structure \\
\hline $24(1201)$ & $24(67)$ & Boden et al. (1990) [44] & $\begin{array}{l}\text { Abnormal magnetic-resonance scans of the lumbar spine in asymptomatic } \\
\text { subjects: A prospective investigation }\end{array}$ \\
\hline $25(1179)$ & $14(112)$ & Kadaba et al. (1990) [45] & Measurement of lower extremity kinematics during level walking \\
\hline $26(1176)$ & $6(190)$ & Sim and Wright (2005) [46] & $\begin{array}{l}\text { The kappa statistic in reliability studies: Use, interpretation, and sample size } \\
\text { requirements }\end{array}$ \\
\hline $27(1059)$ & $20(82)$ & Enneking et al. (1993) [47] & $\begin{array}{l}\text { A system for the functional evaluation of reconstructive procedures after surgical } \\
\text { treatment of tumors of the musculoskeletal system }\end{array}$ \\
\hline $28(1037)$ & $30(32)$ & Farndale et al. (1982) [48] & $\begin{array}{l}\text { A direct spectrophotometric micro-assay for sulfated glycosaminoglycans in } \\
\text { cartilage cultures }\end{array}$ \\
\hline $29(1026)$ & $28(39)$ & Wakitani et al. (1994) [49] & Mesenchymal cell-based repair of large, full-thickness defects of articular cartilage \\
\hline $30(1010)$ & $11(153)$ & Maher et al. (2003) [50] & Reliability of the PEDro scale for rating quality of randomized controlled trials \\
\hline
\end{tabular}

$T C_{2016}$ total citations from Web of Science Core Collection since publication to the end of 2016, $C_{2016}$ citations in 2016 only 


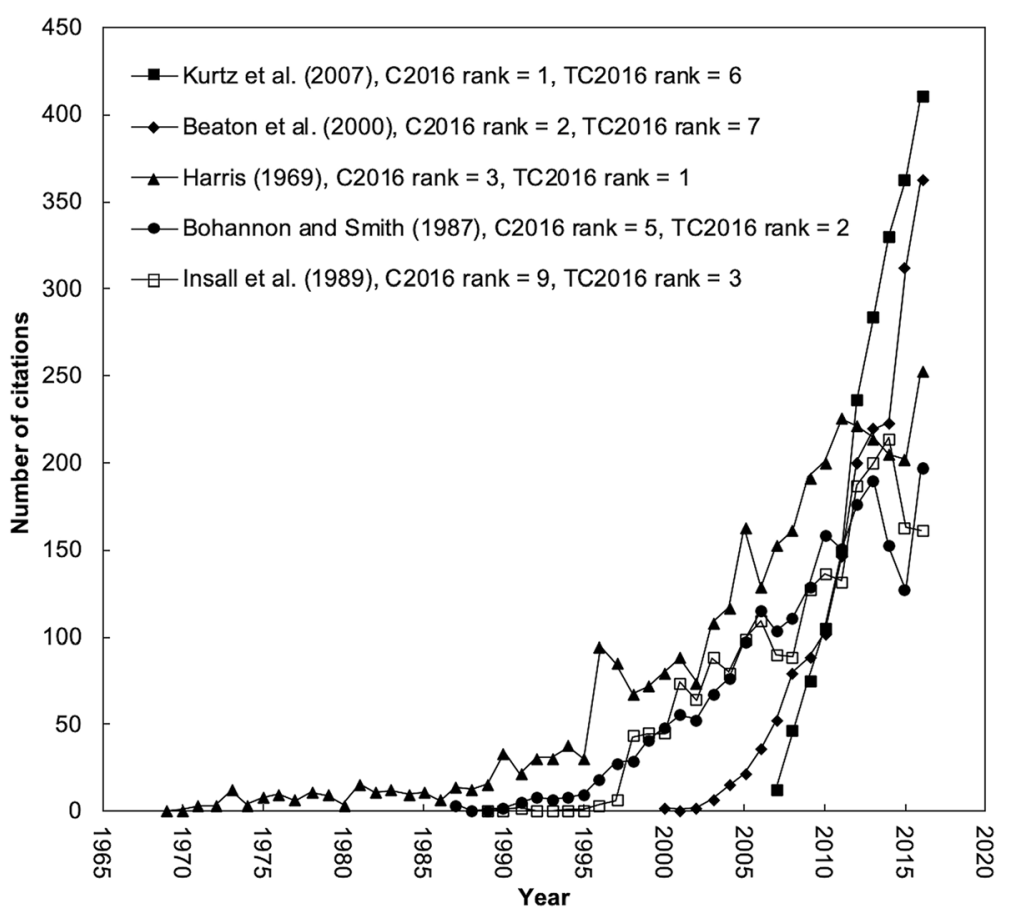

Fig. 2 Citation history of the five classic articles ranked in the top 10 of both $T C_{2016}$ and $C_{2016}$

published one single author classic article. Other 89 authors published only one classic article (Table 2).

\section{Citation history of classic articles}

Table 3 shows the 30 classic articles in WOS category of orthopedics with both citation numbers and rankings for $T C_{2016}$ and $C_{2016}$. Total citations indicated high impact or visibility of an article in a research field. Due to the citations of publications in WOS Core Collection were updated weekly, the total citation number an article has since its publication to the end of $2016\left(T C_{2016}\right)$ was utilized $[9,10]$. The advantage of $T C_{2016}$ is that they remain invariable and ensure repeatability compared with the index of citation from WOS Core Collection [12]. The history of a publication's citations with time has long been studied [51]. The citation history shows characteristics of the influence of an article after its publication. The highly cited articles would not always have high influence or visibility in research society [52]. Five of the top 10 articles $\left(T C_{2016}>1800\right)$ still have a $C_{2013}$ ranked in the top 10 .

Figure 2 shows the citation history of classic articles that were ranked among the top 10 in both $T C_{2016}$ and $C_{2016}$. Although some recently published articles within the past few years had great potential, they did not have a high $T C_{2016}$. Thus indicator of $C_{2016}$ would be interesting to show high impact in 2016. A typical example is the article entitled "Projections of primary and revision hip and knee arthroplasty in the United States from

Table 4 The characteristic of highly cited and the most impact classic articles

\begin{tabular}{llllll}
\hline $\begin{array}{l}\text { Rank } \\
\text { (TC2016) }\end{array}$ & $\begin{array}{l}\text { Rank } \\
\text { (C2016) }\end{array}$ & References (year) & Country & Affiliation & Article title \\
\hline $6(2012)$ & 1 (411) & Kurtz et al. (2007) [22] & USA & Exponent Inc. & $\begin{array}{l}\text { Projections of primary and revision hip and knee arthroplasty } \\
\text { in the United States from 2005 to 2030 }\end{array}$ \\
7 (1870) & 2 (363) & Beaton et al. (2000) [28] & Canada & Michael's Hospital & $\begin{array}{l}\text { Guidelines for the process of cross-cultural adaptation of } \\
\text { self-report measures }\end{array}$ \\
$1(3470)$ & 3 (253) & Harris (1969) [23] & USA & $\begin{array}{l}\text { Massachusetts } \\
\text { General Hospital }\end{array}$ & $\begin{array}{l}\text { Traumatic arthritis of hip after dislocation and acetabular } \\
\text { fractures: treatment by mold arthroplasty: an end-result } \\
\text { study using a new method of result evaluation }\end{array}$ \\
$2(2169)$ & 5 (197) & Bohannon and Smith.(1987) [24] & USA & $\begin{array}{l}\text { Southeastern Regional } \\
\text { Rehabilitation Center }\end{array}$ & $\begin{array}{l}\text { Interrater reliability of a modified Ashworth scale of muscle } \\
\text { spasticity }\end{array}$ \\
$3(2161)$ & 9 (161) & Insall et al.(1989) [25] & USA & $\begin{array}{l}\text { Hospital for Special } \\
\text { Surgery }\end{array}$ & Rationale of the knee society clinical rating system \\
\hline
\end{tabular}

$T_{2016}$ total citations from Web of Science Core Collection since publication to the end of 2016, $C_{2016}$ citations in 2016 only 


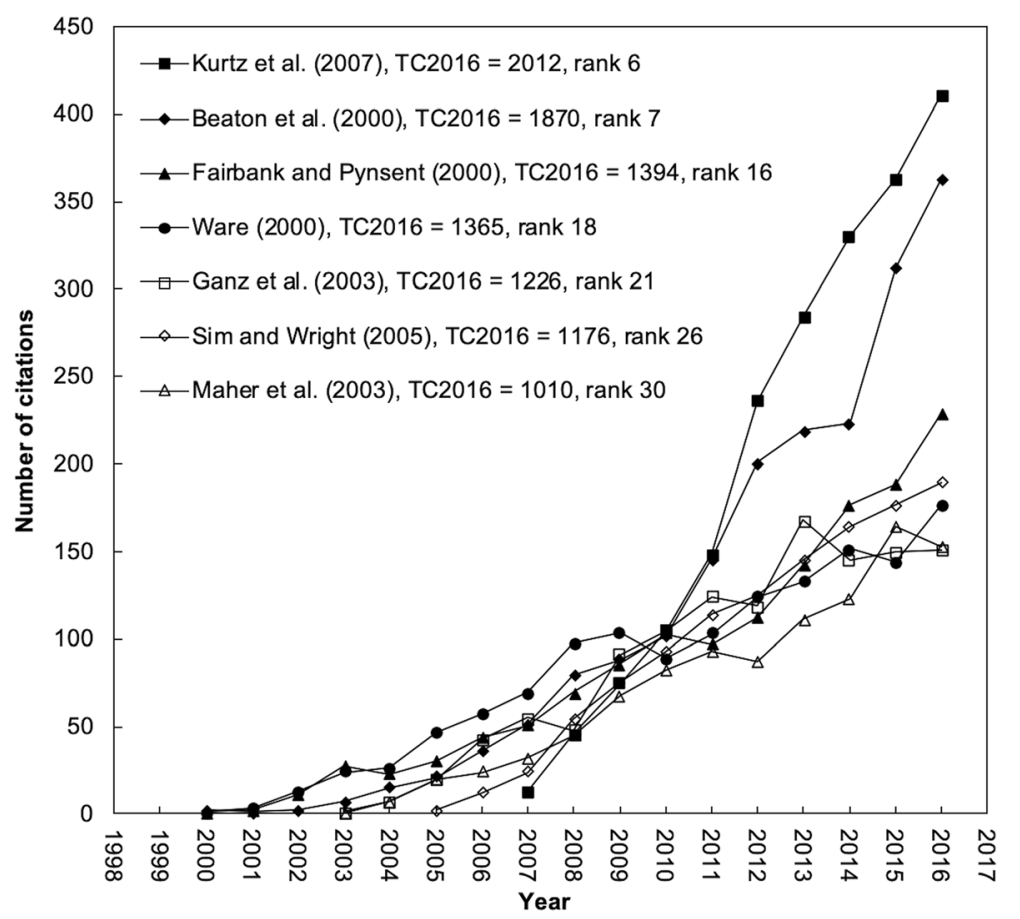

Fig. 3 Seven classic articles with sharp increasing citation trend

2005 to 2030" [22] which was the most impact classic article in 2016 with $C_{2016}$ of 411 . A sharply increasing trend of citations can be found in this article. Similarly, the article entitled "Guidelines for the process of cross-cultural adaptation of self-report measures" had the same impact trend as the article by Beaton et al. [28] in the last decade. Other three articles including Harris et al. [23], Bohannon and Smith [24], and Insall et al. [25] had low citations after their publication and then had an increasing trend in the last 10 years. Classic articles by Fairbank and Pynsent [37], Ware [39], Ganz et al. [41], Sim and Wright [46], and Maher et al. [50] also had sharply increasing citations after publication. Table 4 reveals characteristic of highly cited and the most impact classic articles. The five classic articles were highlighted as follows:

Projections of primary and revision hip and knee arthroplasty in the USA from 2005 to 2030 [22] with $C_{2016}$ of 411 and $T C_{2016}$ of 2012.

Based on NIS, the study collected a substantially large number of discharge records, and revealed the information of the demand for primary and revision hip and knee arthroplasties in the USA through 2030 for the first time. It helped to quantify the expected number of hip and knee revision arthroplasties in the future. It also laid the necessary foundation for subsequent cost-benefit analysis nationally, to measure the increasing societal impact of revision arthroplasty in the USA.

Guidelines for the process of cross-cultural adaptation of self-report measures [28] with $C_{2016}$ of 363 and $T C_{2016}$ of 1870.

With the increasing number of multinational and multicultural research projects, there is a growing need to adapt the language of health status measures. The term "cross-cultural adaptation" is used to describe a process that involves both language (translation) and cultural adaptation issues in the process of preparing a questionnaire. This paper firstly presented a guideline for the process of cross-cultural adaptation of self-report measures, allowing equal efforts to collect data in crossnational studies and to avoid the selection bias.

Traumatic arthritis of hip after dislocation and acetabular fractures: treatment by mold arthroplasty: an end-result study using a new method of result evaluation [23] with $C_{2016}$ of 253 and $T C_{2016}$ of 3470 .

The Harris Hip Score was initially introduced in this paper as a research tool to assess the clinical results of mold cup arthroplasty for traumatic hip arthritis. It made it possible for surgeons to compare their surgical outcomes in the literature. And it is the most widely 
Table 5 Six high impact sleeping beauties in Web of Science category of orthopedics

\begin{tabular}{llllll}
\hline$C_{2016}$ & $T_{2016}$ & $L_{D}$ & $L_{L D}$ & $L_{H}$ & References \\
\hline 78 & 1331 & 17 & 12 & 36 & Outerbridge (1961) [21] \\
85 & 1440 & 22 & 22 & 12 & Delee and Charnley (1976) [36] \\
110 & 1771 & 19 & 18 & 11 & Gruen et al. (1979) [32] \\
159 & 1674 & 13 & 13 & 14 & Tegner and Lysholm (1985) [34] \\
107 & 2058 & 11 & 11 & 10 & Constant and Murley (1987) [27] \\
161 & 2161 & 9 & 7 & 9 & Insall et al. (1989) [25] \\
\hline
\end{tabular}

$T C_{2016}$ the total citations since publication to the end of the last year (2016), $C_{2016}$ the total citations in recent year (the last year 2016) only, $L_{D}$ length of the deep sleep (year), $L_{\mathrm{LD}}$ length of the less deep sleep (year), $L_{H}$ years to reach 100 annual citations after the less deep sleep (year)

used physician-assessed measurement of hip function after total hip arthroplasty.

Interrater reliability of a modified Ashworth scale of muscle spasticity [24] with $C_{2016}$ of 197 and $T C_{2016}$ of 2169.

The modified Ashworth scale is the most common clinical scale used to measure the increase of muscle tone and to monitor the course of disease. It was the first time that the concept of "Modified Ashworth Scale" had been proposed and that "grade 1+" had been added in the definitions. Meanwhile, the authors graded the elbow flexor muscle spasticity of 30 patients with intracranial lesions and proved the reliability of "modified Ashworth scale."
Rationale of the knee society clinical rating system [25] with $C_{2016}$ of 161 and $T C_{2016}$ of 2161 .

This paper presented a newly developed rating system for the knee. The knee society clinical rating system has been widely validated. The unified usage of it allows clinicians across the world to objectively compare their operational outcomes.

Figure 3 shows trends of seven classic articles with sharp increasing in citations. These articles might be high impact in WOS category of orthopedics. In addition, classic author J.E. Ware also published the three classic articles about MOS 36-Item short-form [53-55].

\section{Classic sleeping beauties in web of science category of orthopedics}

A "sleeping beauty" is a term that describes a research article that remains relatively uncited for a time and then suddenly bursts out. Van Raan [12, 56] defined the three characteristics of "sleeping beauties" to be depth of sleep, length of sleep, and awakening intensity.

1. The depth of sleep, where an article receives at most one citation on average per year (deep sleep), or between one to two citations per year during a specific period (less deep sleep)

2. The length of sleep-the duration of the above period

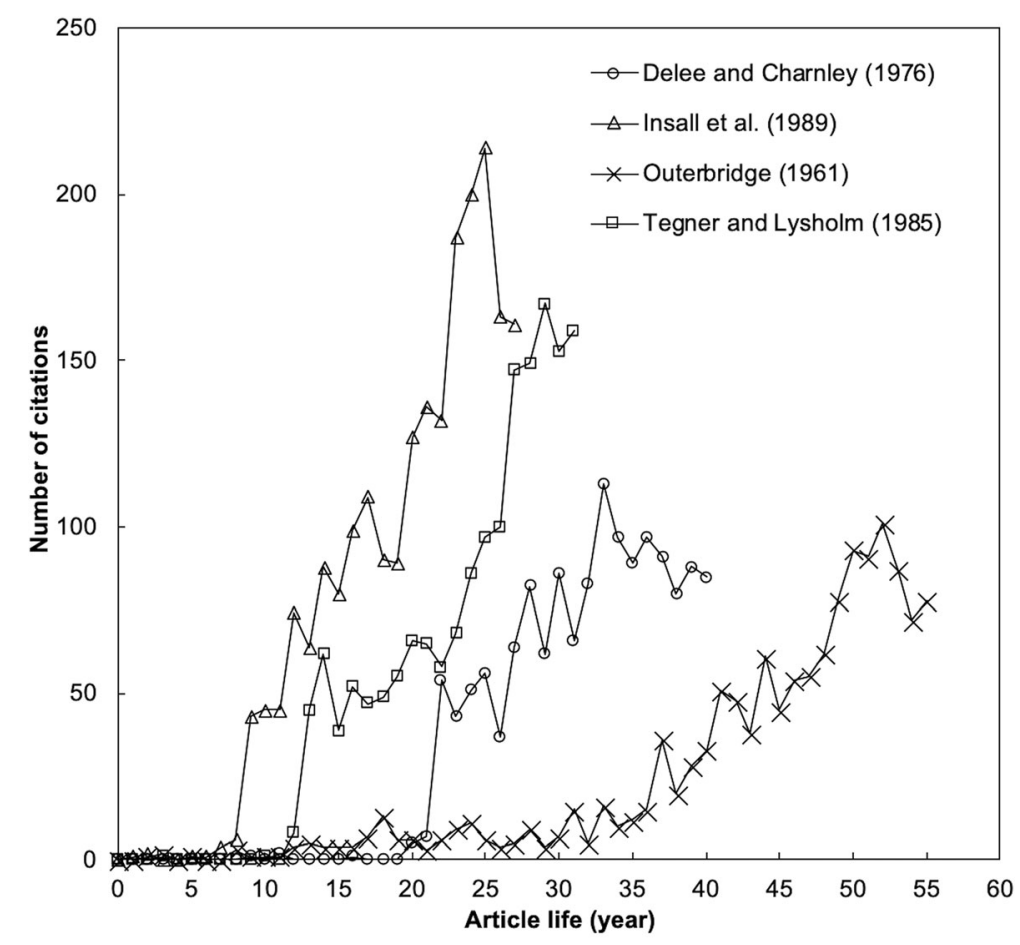

Fig. 4 Four high impact sleeping beauty lives 
3. The intensity of the wakeup period: the number of citations per year for 4 years following the sleeping period

Furthermore, long sleep and high impact sleeping beauties were also discussed [12]. Table 5 lists six high impact sleeping beauties in Web of Science category of orthopedics [12]. Figure 4 shows typical citation curves for four of them. The life of the article by Delee and Charnley [36] shown in Fig. 3 had the longest sleeping period with the deep sleep and the less deep sleep of 22 years respectively. The article by Outerbridge [21] was the earliest sleeping beauty while the article by Insall et al. [25] was the latest one in Web of Science category of orthopedics. Articles by Insall et al. [25] and Tegner and Lysholm [34] had higher impact in recent year. Furthermore, the article by Tegner and Lysholm kept in a plateau for 7 years after its sleep for 13 years and then "wake up" again to reach a high position in short period.

\section{Conclusion}

The bibliometric analysis provides a comprehensive overview of the most influential publications in the field of orthopedics. Based on our analysis, the decade with the most articles was the 1980s. All included articles belong to the document type of article and were written in English. The citation history of classic articles might serve as a guide to the understanding of the discipline.

\section{Abbreviations}

JCR: Journal Citation Reports; SCI-EXPANDED: Science Citation Index Expanded; UK: United Kingdom; WOS: Web of Science

\section{Acknowledgements}

None.

\section{Authors' contributions}

YL and GX, Data analysis and writing, XL and YH - Data collection and study design. All authors read and approved the final manuscript.

\section{Funding}

None.

\section{Availability of data and materials}

The data was all shown in the manuscript.

\section{Ethics approval and consent to participate}

Not applicable.

\section{Consent for publication}

Not applicable.

\section{Competing interests}

The authors declare that they have no competing interests.

\section{Author details}

${ }^{1}$ Department of Plastic Surgery, Peking Union Medical College (PUMC) Hospital, PUMC and Chinese Academy of Medical Sciences, Beijing, China. ${ }^{2}$ Department of Liver Surgery, Peking Union Medical College (PUMC) Hospital, PUMC and Chinese Academy of Medical Sciences, Beijing, China.

${ }^{3}$ Trend Research Centre, Asia University, No. 500, Lioufeng Road, Wufeng,
Taichung Country 41354, Taiwan. ${ }^{4}$ Peking Union Medical College Hospital, No. 1, Shuaifuyuan, Dongcheng District, Beijing, China.

Received: 3 March 2019 Accepted: 25 June 2019

Published online: 19 July 2019

\section{References}

1. Ponseti IV. History of orthopaedic surgery. lowa Orthop J. 1991;11:59-64.

2. Gehrig LM. Orthopaedic surgery. Am J Surg. 2011;202(3):364-8.

3. Ninomiya JT, Dean JC, Incavo SJ. What's new in hip replacement. J Bone Joint Surg Am. 2015:97(18):1543-51.

4. Sabharwal S, Nelson SC, Sontich JK. What's new in limb lengthening and deformity correction. J Bone Joint Surg Am. 2015:97(16):1375-84.

5. Ricci WM, Black JC, McAndrew CM, Gardner MJ. What's new in orthopaedic trauma. J Bone Joint Surg Am. 2015;97(14):1200-7.

6. Rodeo SA, Sugiguchi F, Fortier LA, Cunningham ME, Maher S. What's new in orthopaedic research. J Bone Joint Surg Am. 2014;96(23):2015-9.

7. Pugley AJ, Martin CT, Harwood J, Ong KL, Bozic KJ, Callaghan JJ. Database and registry research in orthopaedic surgery. Part 1: claims-based data. J Bone Joint Surg Am. 2015:97(15):1278-87.

8. Wohlin C. Most cited journal articles in software engineering. Inf Softw Technol. 2005:47(15):955.

9. Wang MH, Fu HZ, Ho YS. Comparison of universities' scientific performance using bibliometric indicators. Malays J Libr Inf Sci. 2011;16(2):1-19.

10. Chuang KY, Wang MH, Ho YS. High-impact papers presented in the subject category of water resources in the essential science indicators database of the Institute for Scientific Information. Scientometrics. 2011;87(3):551-62.

11. Long $X$, Huang JZ, Ho YS. A historical review of classic articles in surgery field. Am J Surg. 2014;208(5):841-9.

12. Ho YS, Hartley J. Classic articles in psychology in the science citation index expanded: a bibliometric analysis. Br J Psychol. 2016;107(4):768-80.

13. Ho YS. Classic papers published by Taiwanese scientists in the science citation index expanded: a bibliometric study. COLLNET Journal of Scientometrics and Information Management. 2018;12(1) https://doi.org/1 0.1080/09737766.2017.1400752

14. Li Z, Ho YS. Use of citation per publication as an indicator to evaluate contingent valuation research. Scientometrics. 2008;75(1):97-110.

15. Ho YS, Fu HZ. Mapping of metal-organic frameworks publications: a bibliometric analysis. Inorg Chem Commun. 2016;73:174-82.

16. Chiu WT, Ho YS. Bibliometric analysis of homeopathy research during the period of 1991 to 2003. Scientometrics. 2005;63(1):3-23.

17. Hsieh WH, Chiu WT, Lee YS, Ho YS. Bibliometric analysis of patent ductus arteriosus treatments. Scientometrics. 2004;60(2):205-15.

18. Zhang W, Moskowitz RW, Nuki G, Abramson S, Altman RD, Arden N, Bierma-Zeinstra S, Brandt KD, Croft P, Doherty M, Dougados M, Hochberg M, Hunter DJ, Kwoh K, Lohmander LS, Tugwell P. OARSI recommendations for the management of hip and knee osteoarthritis, part II: OARSI evidencebased, expert consensus quidelines. Osteoarthr Cartil. 2008;16(2):137-62.

19. Ho YS, Satoh H, Lin SY. Japanese lung cancer research trends and performance in science citation index. Intern Med. 2010;49(20): 2219-28

20. Yeung AWK, Ho YS. Identification and analysis of classic articles and sleeping beauties in neurosciences. Curr Sci. 2018; in press

21. Outerbridge RE. The etiology of chondromalacia patellae. J Bone Joint Surg Br Vol. 1961:43(4):752-7.

22. Kurtz S, Ong K, Lau E, Mowat F, Halpern M. Projections of primary and revision hip and knee arthroplasty in the United States from 2005 to 2030 . J Bone Joint Surg (Am Vol). 2007;89A(4):780-5.

23. Harris WH. Traumatic arthritis of hip after dislocation and acetabular fractures: treatment by mold arthroplasty: an end-result study using a new method of result evaluation. J Bone Joint Surg (Am Vol). 1969;A51(4):737-55.

24. Bohannon RW, Smith MB. Interrater reliability of a modified Ashworth scale of muscle spasticity. Phys Ther. 1987;67(2):206-7.

25. Insall JN, Dorr LD, Scott RD, Scott WN. Rationale of the knee society clinical rating system. Clin Orthop Relat Res. 1989;248:13-4.

26. Caplan Al. Mesenchymal stem cells. J Orthop Res. 1991:9(5):641-50

27. Constant CR, Murley AHG. A clinical method of functional assessment of the shoulder. Clin Orthop Relat Res. 1987:214:160-4.

28. Beaton DE, Bombardier C, Guillemin F, Ferraz MB. Guidelines for the process of cross-cultural adaptation of self-report measures. Spine. 2000; 25(24):3186-91. 
29. Brooker AF, Bowerman JW, Robinson RA, Riley LH. Ectopic ossification following total hip replacement: incidence and a method of classification. J Bone Joint Surg (Am Vol). 1973;A55(8):1629-32.

30. Gustilo RB, Anderson JT. Prevention of infection in the treatment of one thousand and twenty-five open fractures of long bones: retrospective and prospective analyses. J Bone Joint Surg (Am Vol). 1976;58(4):453-8.

31. Roland M, Morris R. A study of the natural history of back pain. Part I. development of a reliable and sensitive measure of disability in low-back pain. Spine. 1983;8(2):141-4.

32. Gruen TA, Mcneice GM, Amstutz HC. "Modes of failure" of cemented stemtype femoral components: a radiographic analysis of loosening. Clin Orthop Relat Res. 1979:141:17-27.

33. Kitaoka HB, Alexander IJ, Adelaar RS, Nunley JA, Myerson MS, Sanders M. Clinical rating systems for the ankle-hindfoot, midfoot, hallux, and lesser toes. Foot Ankle Int. 1994;15(7):349-53.

34. Tegner $Y$, Lysholm J. Rating systems in the evaluation of knee ligament injuries. Clin Orthop Relat Res. 1985;198:43-9.

35. Mankin HJ, Dorfman H, Lippiell L, Zarins A. Biochemical and metabolic abnormalities in articular cartilage from osteo-arthritic human hips. II. Correlation of morphology with biochemical and metabolic data. J Bone Joint Surg (Am Vol). 1971;A53(3):523-37.

36. Delee JG, Charnley J. Radiological demarcation of cemented sockets in total hip replacement. Clin Orthop Relat Res. 1976;121:20-32.

37. Fairbank JCT, Pynsent PB. The Oswestry disability index. Spine. 2000;25(22): 2940-52.

38. Albrektsson T, Brånemark PI, Hansson HA, Lindström J. Osseointegrated titanium implants: requirements for ensuring a long-lasting, direct bone-to-implant anchorage in man. Acta Orthop Scand. 1981; 52(2):155-70.

39. Ware JE. SF-36 health survey update. Spine. 2000;25(24):3130-9.

40. Neer CS. Anterior acromioplasty for chronic impingement syndrome in shoulder: a preliminary report. J Bone Joint Surg (Am Vol). 1972;A54(1):41-50.

41. Ganz R, Parvizi J, Beck M, Leunig M, Notzli H, Siebenrock KA. Femoroacetabular impingement: a cause for osteoarthritis of the hip. Clin Orthop Relat Res. 2003;417:112-20.

42. Lysholm J, Gillquist J. Evaluation of knee ligament surgery results with special emphasis on use of a scoring scale. Am J Sports Med. 1982;10(3):150-4.

43. Carter DR, Hayes WC. The compressive behavior of bone as a two-phase porous structure. J Bone Joint Surg (Am Vol). 1977:59(7):954-62.

44. Boden SD, Davis DO, Dina TS, Patronas NJ, Wiesel SW. Abnormal magneticresonance scans of the lumbar spine in asymptomatic subjects: a prospective investigation. J Bone Joint Surg (Am Vol). 1990;72A(3):403-8

45. Kadaba MP, Ramakrishnan HK, Wootten ME. Measurement of lower extremity kinematics during level walking. J Orthop Res. 1990;8(3):383-92.

46. Sim J, Wright CC. The kappa statistic in reliability studies: use, interpretation, and sample size requirements. Phys Ther. 2005;85(3):257-68.

47. Enneking WF, Dunham W, Gebhardt MC, Malawar M, Pritchard DJ. A system for the functional evaluation of reconstructive procedures after surgical treatment of tumors of the musculoskeletal system. Clin Orthop Relat Res. 1993;286:241-6.

48. Farndale RW, Sayers CA, Barrett AJ. A direct spectrophotometric micro-assay for sulfated glycosaminoglycans in cartilage cultures. Connect Tissue Res. 1982;9(4):247-8

49. Wakitani S, Goto T, Pineda SJ, Young RG, Mansour JM, Caplan Al, Goldberg VM. Mesenchymal cell-based repair of large, full-thickness defects of articular cartilage. J Bone Joint Surg (Am Vol). 1994;76A(4):579-92.

50. Maher CG, Sherrington C, Herbert RD, Moseley AM, Elkins M. Reliability of the PEDro scale for rating quality of randomized controlled trials. Phys Ther. 2003:83(8):713-21.

51. Avramescu A. Actuality and obsolescence of scientific literature. J Am Soc Inf Sci. 1979:30(5):296-303.

52. Ho YS. A bibliometric analysis of highly cited articles in materials science. Curr Sci. 2014;107(9):1565-72.

53. Ware JE, Sherbourne CD. The MOS 36-item short-form health survey (SF-36). I. Conceptual-framework and item selection. Med Care. 1992;30(6):473-83.

54. Mchorney CA, Ware JE, Raczek AE. The MOS 36-item short-form health survey (SF-36). II. Psychometric and clinical-tests of validity in measuring physical and mental-health constructs. Med Care. 1993;31(3):247-63.
55. Ware JE, Kosinski M, Keller SD. A 12-item short-form health survey: construction of scales and preliminary tests of reliability and validity. Med Care. 1996;34(3):220-33.

56. van Raan AFJ. Sleeping beauties in science. Scientometrics. 2004;59(3):467-72.

\section{Publisher's Note}

Springer Nature remains neutral with regard to jurisdictional claims in published maps and institutional affiliations.
Ready to submit your research? Choose BMC and benefit from:

- fast, convenient online submission

- thorough peer review by experienced researchers in your field

- rapid publication on acceptance

- support for research data, including large and complex data types

- gold Open Access which fosters wider collaboration and increased citations

- maximum visibility for your research: over $100 \mathrm{M}$ website views per year

At BMC, research is always in progress.

Learn more biomedcentral.com/submissions 